\title{
KARAKTER DAN KUALITAS GONDORUKEM KUNA HASIL PENEMUAN DI PEMUKIMAN PECINAN KUTOARJO KABUPATEN PURWOREJO
}

\author{
Yustinus Suranto \\ Fakultas Kehutanan, Universitas Gajah Mada \\ Email:suranto@ugm.ac.id
}

\begin{abstract}
Abstrak : Pada 26 April 2016, wajan raksasa kuna berukuran besar yang berisi benda padat transparan ditemukan di kawasan Pecinan Kutoarjo Kabupaten Purworejo. Hasil pengamatan sementara di lapangan benda padat tersebut adalah Gondorukem. Ciri-ciri dan kualitas Gondorukem serta latar belakang dihasilkannya benda tersebut merupakan kasus yang menarik untuk dikaji.

Bahan yang diposisikan sebagai objek penelitian adalah gondorukem kuna hasil penemuan di Kecamatan Kutoarjo. Kualitas gondorukem dan sifat-sifatnya ditentukan berdasarkan parameter: warna, titik lunak, nilai komponen mudah menguap, dan nilai bilangan asam. Secara berurutan, masing-masing parameter itu ditentukan dengan metode: Lovibond Comparator, SNI 7636: 2011, penguapan, serta RSNI3 7636: 2010 dengan titrasi kalium hidroksida. Pengujian dilakukan dengan ulangan sebanyak tiga kali. Prediksi jenis industri yang beroperasi pada masa silam dilakukan dengan metode interpretasi berbasis analisis relasional.

Hasil penelitian menyimpulkan empat hal. Pertama, benda kuna hasil temuan adalah gondorukem. Kedua, gondorukem ini berkelas mutu yang diberi kode huruf I dengan peringkat ke-10 dari 15 peringkat yang tersedia. Ketiga, gondorukem kuna memiliki sifat nilai titik lunak yang wajar, kadar komponen menguap pada peringkat yang tinggi, serta nilai bilangan asam pada peringkat yang rendah. Keempat, keberadaan gondorukem kuna yang soliter dan murni di dalam wajan berdiameter 270 sentimeter dengan kedalaman cekungan 90 sentimeter yang berada di atas tungku terbuat dari batu merah mengindikasikan adanya kegiatan industri pengolahan getah pinus menjadi produk gondorukem pada masa silam di kawasan Pecinan di Kecamatan Kutoarjo.
\end{abstract}

Kata Kunci : Wajan kuna, gondorukem, Kutoarjo, Ciri-ciri dan Kualitas, Lovibond Comparator

\begin{abstract}
Ancient giant pan containing transparent solid objects was found in the Chinatown settlement of Kutoarjo in Purworejo District on April 26th, 2016. The results of the initial observations on the field to these solid objects were Gondorukem. The characteristics, qualities and production background of Gondorukem were interesting cases to study.

Materials used as a research object was rosin found in Kutoarjo sub-district. Rosin's quality and characteristics were determined by parameters of: color, softening point, volatile component and acid number. Sequentially, each parameter was determined by using the method of: Lovibond Comparator, SNI 7636: 2011 for softening point, evaporation, and RSNI3 7636: 2010 with potassium hydroxide titration. Testing was elaborated on three replications. Determining what type of industry might exist in the past was done by interpretation based relational analysis method.

The study concluded four items. First, the found object was rosin. Second, the rosin's quality was I class which rated on 10th out of 15 rating level. Third, the character of enchient rosin were as follows: equitable value of softening point, high level of evaporated components, and low level of acid number. Fourth, solitary existence of pure ancient rosin in the giant pan indicates that the possible type of related industry was rosin industry which process pine resin into rosin.
\end{abstract}

Keywords: Old Gridlle, rosin, Kutoarjo, Character ans Quality, Lovibond Comparator 


\section{PENDAHULUAN}

Pada 26 April 2016, Balai Pelestarian Cagar Budaya Jawa Tengah (BPCB Jawa Tengah) menyelamatkan dan menyimpan benda-benda kuna yang ditemukan di pemukiman Pecinan, Kecamatan Kutoarjo, Kabupaten Purworejo. Benda-benda kuna ini antara lain berupa wajan berukuran berdiameter 270 sentimeter dengan kedalaman cekungan 90 sentimeter yang terbuat dari logam beserta isinya yang berupa benda padat yang bersifat tembus cahaya dan berwarna coklat gelap kehitaman. Benda-benda kuna tinggalan masa lalu ini berpotensi sebagai sumber data arkeologi.

Dalam rangka memberi informasi secara lebih detil terhadap data arkeologi ini, penelitian terhadap benda kuna yang berupa benda padat tetapi bersifat tembus cahaya dan berwarna coklat gelap kehitaman itu perlu dilakukan. Penelitian tersebut diarahkan untuk menjawab beberapa pertanyaan berikut: (1) apa jenis benda kuna yang padat tetapi tembus cahaya itu; (2) bagaimana cara pengujian untuk menentukan kualitas benda kuna; (3) seberapa tinggi peringkat mutu benda kuna ini; dan (4) Latar belakang dihasilkannya benda tersebut atau jenis industri apa yang beroperasi di masa silam.

Contoh uji dicuplik dari benda padat transparan tersebutPengidentifikasi terhadap contoh uji menghasilkan empat hal berikut. Pertama, berdasarkan identifikasi terhadap karakter fisik benda, khususnya dalam hal: warna benda, kondisi ketransparanan atau daya tembus cahaya terhadap benda, kondisi kerapuhan benda, serta struktur dan posisi bidang-bidang patahan yang berada pada permukaan benda dan sekaligus yang membentuk benda itu, maka benda kuna tersebut adalah gondorukem, sehingga dapat disebut gondorukem kuna. Kedua, berdasarkan pengamatan secara visual terhadap warna dan tingkat kejernihannya, maka gondorukem kuna ini merupakan gondorukem yang berkualitas rendah. Pendeskripsian yang lebih presisi dan kuantitatif terhadap kualitas gondorukem kuna dilakukan melalui prosedur baku. Ketiga, penentuan secara lebih detil dan lebih kuantitatif terhadap kualitas gondorukem dapat ditentukan melalui aktivitas pengujian di laboratorium yang dilakukan berdasarkan beberapa parameter, antara lain parameter: warna, titik lunak, dan kadar kotoran. Keempat, laboratorium yang dapat digunakan untuk menentukan kualitas gondorukem adalah laboratorium milik Pabrik Gondorukem dan Terpentin (PGT) yang berlokasi antara lain di Ponorogo, Sapuran, Cimanggu, dan Pemalang. Pabrik-pabrik gondorukem dan terpentin tersebut dikelola oleh Perum Perhutani.

Sehubungan dengan hal itu, maka penelitian terhadap kualitas gondorukem kuna hasil penemuan di Kutoarjo ini dilakukan. Melalui penelitian ini diharapkan agar diperoleh data hasil penelitian yang berfungsi untuk memperkaya ketersediaan informasi tentang sumber daya arkeologis, sehingga interpretasi terhadap kegiatan pada masa lalu dapat dideskripsikan secara lebih presisi, khususnya kegiatan industri di daerah Pecinan di Kecamatan Kutoarjo.

Penelitian ini bertujuan untuk mencapai empat hal: (1) mengetahui jenis benda yang ditemukan, (2) menentukan kelas kualitas benda temuan, (3) mengetahui sifat-sifat benda temuan, (4) mengetahui jenis indusri yang berkait dengan benda temuan.

\section{TINJAUAN PUSTAKA}

\section{a. Gondorukem sebagai Hasil Hutan}

Gondorukem (resina colophonium) adalah benda bersifat padat dan berwarna kuning kecokelatan sebagai hasil yang diperoleh dari proses distilasi (penyulingan) terhadap getah pohon tusam atau pinus (Pinus merkusii Jungh et de Vriese). Banyak nama lain digunakan untuk menyebut gondorukem, yaitu: gum rosin, pine resin, resin, rosin, dan siongka. Secara kimiawi, gondorukem tersusun atas asam-asam resin antara lain berbagai isomer anhidrida asam abietat $\mathrm{C} 19 \mathrm{H} 29 \mathrm{COOH}$, abietat anhidrida C40H58O3, dan hidrokarbon yang merupakan zat tak tersabun (Kirk and Othmer, 2007).

Selain gondorukem, proses distilasi terhadap getah pinus juga diperoleh terpentin. Di dalam distilasi, gondorukem merupakan hasil yang tertinggal di dalam tangki distilasi, sedangkan terpentin merupakan uap yang keluar meninggalkan tangki distilasi. Ketika keluar dari tangki destilasi, terpentin berupa uap ini diberikan perlakuan kondensasi, sehingga terjadi perubahan status terpentin dari status gas menjadi status cairan. Terpentin dalam bentuk cair ditampung dalam tangki terpentin yang terpisah dari tangki distilasi (Abdulgani, 2002).

Getah pohon pinus yang dinisbatkan sebagai bahan pada pengolahan yang menghasilkan gondorukem dan terpentin itu diperoleh melalui aktivitas 
pemanenan getah dari pohon-pohon pinus. Pemanenan getah dilakukan dengan cara penyadapan terhadap batang pohon pinus (Suryamiharja dan Buharman, 1986). Penyadapan getah dilakukan dengan cara melukai kayu yang menyusun batang bagian-dalam pada pohon pinus. Perlakuan pelukaan ini tidak hanya tertuju secara terbatas pada bagian kulit batang saja, melainkan tertuju secara lebih mendalam sehingga mencapai bagian kayu sebagai penyusun bagian dalam batang (Endom, 1989). Pelukaan secara demikian perlu dilakukan karena saluran getah resin yang berperan sebagai kantong-kantong penyimpan resin itu berada di dalam kayu. Saluran resin menjadi komponen penyusun struktur kayu pada pohon pinus (Martawijaya, dkk., 1989). Pohon pinus merupakan komponen utama penyusun hutan, yaitu hutan pinus. Dengan demikian, getah pinus merupakan hasil hutan yang dikategorikan hasil hutan bukan kayu (Soenardi, 1980; Kasmudjo, 2011).

Penyadapan getah pinus dapat dilakukan terhadap pohon yang berumur 20 sampai dengan 50 tahun. Diatas umur ini, pohon pinus akan menghasilkan getah pada tingkatan produktivitas yang rendah, sehingga tidak layak dari sudut pandang ekonomi untuk diusahakan sebagai sumber getah. Dengan alasan demikian, maka hutan pinus pada umur 50 tahun akan ditebang dengan pola tebang habis (Astuti, 2015). Penebangan ini merupakan kegiatan pemanenan hasil hutan berupa kayu. Lahan kawasan hutan pinus pasca penebangan ini akan ditanami kembali dengan bibit baru yang lebih unggul jenis tanaman pinus (Siregar, 2005). Penanaman ini menandai dimulainya siklus baru dalam pengusahaan hutan dengan tujuan untuk menghasilkan getah pinus dan kayu pinus pada daur berikutnya. Siklus berulang yang terdiri atas aktivitas penanaman pada awal daur dan pemanenan getah sepanjang durasi waktu tertentu serta aktivitas pemanenan kayu pada akhir daur ini merupakan pola pengusahaan hutan pinus yang lestari dan berkelanjutan (Soeseno dkk., 1992).

Kualitas getah yang dihasilkan dari pemanenan getah pohon pinus itu sangat bervariasi. Variabilitas kualitas getah ditentukan oleh banyak faktor. Faktor-faktor itu meliputi: lokasi geografis keberadaan hutan pinus dan tingkat kesuburan lahan, jenis dan varietas pohon pinus, umur pohon pinus ketika disadap, teknologi penyadapan getah pinus, situasi klimatologis (cuaca dan musim) ketika dilakukan penyadapan getah, serta profesionalitas, keterampilan, dan tingkah laku para penyadap getah pinus (Sumantri, 1991). Faktor teknologi penyadapan getah berkait dengan bentuk geometri pelukaan sadap dan cairan asam sebagai penstimulan terhadap keluarnya getah. Cairan asam ini tersusun atas air, asam sulfat (H2SO4) dan asam nitrat (HNO3). Bentuk pelukaan dan komposisi cairan asam berpengaruh terhadap jumlah dan kualitas getah (Sumantri dan Endom, 1989). Faktor terakhir berpengaruh sangat besar terhadap kualitas getah pinus. Para penyadap getah pinus tidak jarang menambahkan benda-benda tertentu ke dalam getah pinus agar berat getah pinus hasil pemanenan menjadi lebih tinggi, sehingga upah penyadapan yang diterimanya juga menjadi lebih tinggi karena upah ditentukan oleh berat getah pinus yang dipanennya. Benda-benda tertentu yang ditambahkan pada getah pinus itu kemudian berstatus sebagai kotoran yang mengakibatkan penurunan kualitas getah (Perum Perhutani, 1985 dan 1992). Kualitas getah diklasifikasikan menjadi lima kelas kualitas berdasarkan tingkat kemurnian getah dan warna getah. Kelima kualitas getah ini meliputi kualitas: (1) super premium, (2) premium, (3) mutu satu, (4) mutu dua, dan (5) mutu tiga. Getah bermutu satu merupakan larutan getah murni berwarna putih. Getah bermutu dua memiliki warna putih kecoklatan dan getah bermutu tiga berwarna kecoklatan (Badan Standardisasi Nasional, 2001).

Kualitas getah pinus berpengaruh terhadap kualitas gondorukem dan terpentin. Disamping dipengaruhi oleh kualitas getah pinus, kualitas gondorukem dan terpentin juga dipengaruhi oleh kualitas proses pengolahan getah pinus yang mengubah getah menjadi gondorukem dan terpentin (Abdulgani, 2002). Proses pengolahan getah pinus menjadi gondorukem dan terpentin disajikan dalam uraian berikut.

\section{b. Pengolahan Getah Pinus menjadi Gondorukem dan Terpentin.}

Proses pengolahan getah pinus menjadi gondorukem dan terpentin dapat dipilah menjadi dua tahap, yaitu (1) pemurnian getah dan (2) distilasi getah. Setiap tahap proses pengolahan tersebut terdiri atas beberapa langkah perlakukan. Pada tahap pemurnian getah terdapat tiga langkah perlakuan yang berlangsung secara berurutan, yaitu langkah: pengenceran dan 
pengendapan serta penyaringan getah. Sementara itu, tahap distilasi terdapat dua langkah yang juga berlangsung secara berurutan, yaitu langkah pemanasan dalam tangki pemasak dan langkah pengemasan gondorukem ke dalam kaleng-kaleng pengemas (Kasmudjo, 2011).

Sebagaimana disebutkan, bahwa tahap pemurnian getah dilakukan dengan tiga langkah perlakuan secara berurutan, yaitu pengenceran dan pengendapan serta penyaringan getah. Setiap langkah perlakuan ini dideskripsikan sebagai berikut.

a. Proses pengenceran, getah ini ditambahkan air bersih dan terpentin masing-masing sebanyak 30\% dari volume getah dan asam oksalat sebanyak 0,2\% dari berat getah. Getah encer ini dipanaskan pada suhu 90-105oC yang disertai dengan pengadukan selama 30 menit.

b. Tahap pengendapan, campuran getah panas diendapkan selama dua jam.

c. Tahap penyaringan, getah disaring dengan penggunakan penyaring berukuran 200 mikron, sehingga diperoleh getah bersih. Getah bersih yang bersuhu 60-90oC ini diproses lebih lanjut dalam tahap distilasi.

d. Tahap distilasi terhadap getah bersih dapat dilakukan dengan memilih satu dari dua metode pemanasan yang tersedia, yaitu metode pemanasan langsung atau metode pemanasan tidak langsung melalui uap panas. Metode pemanasan dengan uap menghasilkan gondorukem dan terpentin dengan kualitas yang lebih tinggi daripada metode pemanasan langsung. Pada metode pemanasan dengan uap juga tersedia dua pilihan teknologi, yaitu pemanasan uap yang berlangsung pada tekanan atmosfer atau pemanasan dengan uap dalam kondisi vacum. Metode pemanasan dengan uap dalam kondisi vakum menghasilkan gondorukem dan terpentin dengan kualitas yang lebih tinggi daripada metode pemanasan uap dalam kondisi tekanan atmosfer (Abdulgani, 2002).

Tahap distilasi dilakukan dengan dua proses berurutan, yaitu pemanasan dalam tangki pemasak dan pengemasan gondorukem ke dalam kaleng-kaleng pengemas. Pada proses pemasakan, getah dipanaskan pada suhu 150-160oC selama 75 menit. Apabila proses distilasi dipilih dengan teknologi vakum, maka kondisi vakum yang diterapkan dalam tangki pemasak adalah pada ukuran minimum minus $40 \mathrm{~kg} / \mathrm{cm} \mathrm{Hg}$. Proses pemasakan ini memisahkan secara gradual gondorukem terhadap terpentin. Dalam pemisahan ini, terpentin keluar secara terus menerus dalam bentuk uap dari tangki pemasak. Uap terpentin dialirkan melalui saluran berbentuk kumparan yang dikenai proses pendinginan sehingga terjadi kondensasi yang mengubah terpentin dari bentuk uap menjadi cairan. Setelah proses pemasakan berlangsung selama durasi waktu tertentu, maka terjadi kondisi yang ditandai dengan tidak adanya lagi terpentin yang dihasilkan dan keluar dari dalam tangki pemasak. Pada kondisi yang demikian ini, maka proses pemasakan dinyatakan berakhir dan di dalam tangki pemasak hanya melulu berisi gondorukem. Gondorukem dipindahkan dari tangki pemasak menuju ke dalam kaleng-kaleng pengemas yang terbuat dari logam. Langkah pemindahan gondorukem yang sekaligus menjadi langkah pengemasan ini merupakan langkah terakhir dari keseluruhan proses pengolahan getah pinus menjadi gondorukem dan terpentin (Abdulgani, 2002).

\section{c. Kualitas Gondorukem dan Metode Penentuannya}

Sebagaimana disebutkan, bahwa mutu gondorukem dipengaruhi oleh banyak faktor. Faktorfaktor tersebut berkait dengan: kondisi hutan pinus, kondisi proses penyadapan, dan kondisi proses pengolahan getah menjadi gondorukem dan terpentin. Variabilitas faktor-faktor tersebut menyebabkan variabilitas kualitas gondorukem dan kualitas terpentin yang dihasilkan dari proses pengolahan getah. Kualitas gondorukem ditetapkan melalui pengujian yang berorientasi pada pengukuran warna gondorukem dan tingkat kejernihannya. Pengukuran warna gondorukem dan penetapan kelas mutu dilakukan dengan metode pembandingan warna antara warna gondorukem teruji terhadap warna standar Lovibond (Abdulgani, 2002).

Berdasarkan warna dan tingkat kejernihannya, Badan Standardisasi Nasional Indonesia/BSNI (2001) mengklasifikasikan kualitas gondorukem menjadi 15 peringkat kelas kualitas. Kelas kualitas 1 sampai dengan 15 tersebut secara berurutan dinamakan sebagai kelas kualitas: XC, XB, XA, X, WW, WG, N, M, K, I, H, G, F, E, dan D. Gerakan pergeseran dari kelas kualitas XC menuju ke kelas kualitas D diiringi dengan pergeseran tingkat kualitas gondorukem yang semakin rendah. Dengan demikian, kelas kualitas XC merupakan kelas kualitas tertinggi dan terbaik, sedangkan kelas kualitas D merupakan kelas kualitas terendah dan terburuk.

Industri gondorukem dan terpentin di Indonesia pada 
saat ini memproduksi dan memperdagangkan secara internasional hanya empat kelas kualitas gondorukem saja, yaitu kualitas: X, WW, WG dan N. Dengan demikian, kelas kualitas M sampai dengan D tidak diproduksi dan juga tidak diperdagangkan. Pergeseran dari kelas mutu $\mathrm{X}$ menuju ke kelas mutu $\mathrm{N}$ ditandai dengan pergeseran penampilan gondorukem dari warna jernih menuju ke warna kuning kecoklatan. Sementara itu, pergeseran dari kelas mutu M menuju ke kelas mutu D ditandai dengan pergeseran penampilan gondorukem dari warna coklat kekuningan menuju ke warna hitam kecoklatan. Gondorukem yang tergolong dari kelas mutu M sampai dengan kelas mutu D, sering disebut sebagai gondorukem tanpa mutu, sehingga spesifikasinya tidak disajikan.

Oleh karena itu, spesifikasi dan informasi tentang gondorukem dengan kelas kualitas: X, WW, WG, dan N saja yang disajikan. $\mathrm{X}$ adalah simbol bagi kualitas utama yang berarti Extra (Rex). Kualitas X ditandai dengan warna jernih kekuning-kuningan pada standar warna Lovibond. WW adalah simbol bagi kualitas pertama yang berarti Water White. Kualitas WW ditandi dengan warna kuning pada standar warna Lovibond. WG adalah simbol bagi kualitas dua yang berarti Window Glass. Kualitas WW ditandai dengan warna kuning kecoklatan pada sandart warna Lovibond. $\mathrm{N}$ adalah simbol bagi kualitas tiga yang berarti Nancy. Kualitas $\mathrm{N}$ ditandai dengan warna kecoklatan pada standar warna Lovibond (BSNI, 2001).

Di dalam konteks penentuan kelas kualitas gondorukem berdasarkan parameter warna, spesifikasi nilai warna ditentukan berdasarkan LICO 620. Sebagaimana disebutkan, bahwa deskripsi warna bagi masing-masing standar mutu kelas X, WW, WG dan N itu menurut Standar SNI disajikan dalam Tabel 1 berikut.

Tabel 1. Kualitas gondorukem berbasis parameter warna

\begin{tabular}{|c|c|c|}
\hline Strindar mitn kelps & Nini & Keterangm \\
\hline $\mathbf{X}$ & 4,0 & Untul w wing paling jerminh \\
\hline WW & 6,0 & 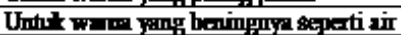 \\
\hline WG & 7,0 & Untu' wring ying bering \\
\hline $\mathbf{N}$ & 9,0 & 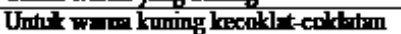 \\
\hline
\end{tabular}

Sebagaimana disebutkan, bahwa penentuan kualitas gondorukem dilakukan terutama dengan mendasarkan pada parameter warna yang ditetapkan melalui metode Lovibond. Selain parameter warna, penentuan kualitas gondorukem juga dilakukan berdasarkan tiga parameter utama yang lain, yaitu parameter: titik lunak, kadar kotoran, dan komponen yang menguap. Titik lunak merupakan nilai yang menggambarkan tinggi-rendahnya suhu yang diperlukan oleh gondorukem untuk melunak atau mulai mencair dan dinyatakan dalam derajat Celcius $\left({ }^{\circ} \mathrm{C}\right)$. Pengukuran dan penentuan titik lunak gondorukem dilakukan berdasarkan SNI 7636: 2011 dengan peralatan cincin dan bola (softening point ring and ball apparatus). Jumlah kotoran merupakan nilai yang menggambarkan jumlah bahan yang dikandung dalam gondorukem yang tidak larut dalam toluol pada kondisi tertentu dan dinyatakan dalam persen (\%). Sementara itu, komponen menguap merupakan nilai yang menggambarkan tentang jumlah bagian yang menguap dari gondorukem setelah dipanaskan pada suhu $150 \pm 5^{\circ} \mathrm{C}$ dan dinyatakan dalam persen (\%). Pengujian komponen yang menguap dilakukan berdasarkan RSNI3 7636: 2010.

Didalam konteks kelas kualitas berdasarkan parameter: titik lunak, kadar komponen yang menguap, dan kadar kotoran tersebut, spesifikasi nilai dan deskripsi bagi masing-masing standar mutu kelas: X, WW, WG dan N itu menurut Standar SNI disajikan dalam Tabel 2 berikut.

Tabel 2. Spesifikasi mutu gondorukem berdasar titik lunak, kadar zat menguap, dan kadar kotoran

\begin{tabular}{|c|c|c|c|}
\hline \multirow{2}{*}{ Standir mmtr } & \multicolumn{3}{|c|}{ Kígi } \\
\hline & Thikhme $\left.0^{\circ} \mathrm{C}\right)$ & 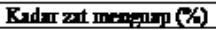 & Kailarkotoran (7) \\
\hline $\bar{x}$ & 378 & $\leq 2$ & $\leq 0,02$ \\
\hline WW & 378 & $\underline{25}$ & 50,05 \\
\hline WG & 376 & $\underline{\underline{c} 2,5}$ & $\leq 0,07$ \\
\hline $\mathbf{N}$ & 374 & $\leq 3$ & $\leq 0,10$ \\
\hline
\end{tabular}

Di samping kee mpat parameter utama itu, kualitas gondorukem juga diatribusi dengan karakterisasi yang mendeskripsikan tentang empat hal. Keempat hal ini meliputi: kadar abu, bilangan asam, bilangan penyabunan, dan bilangan iod. Kadar abu merupakan nilai yang menggambarkan jumlah bahan yang tersisa dari pembakaran terhadap gondorukem yang dilakukan pada suhu $625 \pm 5^{\circ} \mathrm{C}$ dan dinyatakan dalam persen $(\%)$. Bilangan asam merupakan nilai yang menggambarkan tentang jumlah kalium hidroksida dalam miligram yang digunakan untuk menetralkan 1 gram lemak yang terkandung dalam gondorukem. Bilangan penyabunan merupakan nilai yang menggambarkan tentang jumlah kalium hidroksida yang dinyatakan dalam satuan miligram yang digunakan untuk menyabunkan satu gram 
komponen lemak yang terkandung dalam gondorukem. Komponen lemak meliputi asam lemak bebas maupun asam lemak terikat. Sementara itu, bilangan iod merupakan nilai yang menggambarkan tentang jumlah ikatan rangkap yang terkandung dalam persenyawaan gondorukem.

Dengan demikian, penentuan kualitas dan deskripsi untuk mengidnetifikasi gondorukem secara keseluruhan mencakup delapan parameter. Kedelapan parameter itu meliputi: warna, titik lunak, kadar zat menguap, kadar kotoran, kadar abu, bilangan asam, bilangan penyabunan, dan bilangan iod.

\section{d. Penggunaan Gondorukem}

Penggunaan gondorukem dapat dikategorikan kedalam dua kelompok, yaitu (1) penggunaan gondorukem dalam bentuk yang asli tanpa adanya proses modifikasi, dan (2) penggunaan gondorukem dalam bentuk derivat atau turunan gondorukem yang dihasilkan dari proses pengolahan lebih lanjut yang menggunakan gondorukem sebagai bahan baku pengolahan. Gondorukem dalam bentuk yang murni diproduksi oleh PGT milik Perum Perhutani mulai tahun 1974. Sementara itu, turunan gondorukem berupa gliserol rosin ester baru mulai diproduksi pada tahun 2010 oleh Unit gliserol rosin ester pada PGT Pemalang milik Perum Perhutani dengan kapasitas produksi 18.000 ton gliserol rosin ester/tahun (Perum Perhutani, 2010).

Gondorukem termodifikasi dalam bentuk derivat-derivat gondorukem digunakan pada industriindustri: karet tiruan, perekat, tinta cetak, cat pelitur, vernis dan berbagai pelapis pada permukaan kayu, bahkan digunakan pula dalam industri permen karet, dan minuman ringan. Disamping itu, gondorukem dan derivatnya digunakan sebagai bahan pada berbagai jenis industri, antara lain industri-industri yang menghasilkan: resin sintetis, plastik, lem, aspal, bahan politur, lak sintetis. Disamping itu, juga digunakan oleh industri sepatu, dan industri galangan kapal (Suryamiharja dan Buharman, 1986).

Gondorukem dalam bentuknya yang asli berfungsi perekat dan pelapis pada berbagai jenis industri. Pada industri kertas, gondorukem digunakan sebagai bahan pengisi pada pembuatan lembaran kertas. Pada industri tinta bagi industri percetakan, gondorukem digunakan sebagai bahan tambahan pada pembuatan tinta cetak. Pada industri produk-produk pelapisan permukaan, gondorukem digunakan sebagai bahan untuk membuat cat, politur, dan vernis untuk pelapis pada permukaan kayu. Pada industri elektronika, gondorukem digunakan untuk pelapis yang berfungsi sebagai isolator arus listrik. Pada industri batik, gundorukem digunakan sebagai bahan pencampur lilin sehingga diperoleh "malam" yang digunakan sebagai pembentuk pola-pola dalam proses membatik. Pada industri sabun, gundorukem digunakan sebagai bahan "sizing" atau bahan pendarih. Dalam industri ini, gundorukem digunakan sebanyak 5-10\% dari berat sabun. Gondorukem juga digunakan sebagai bahan dalam pembuatan pembuatan minyak rosin (Suryamiharja dan Buharman, 1986).

Sebagaimana disebutkan, bahwa gondorukem dalam bentuknya yang asli diklasifikasikan kualitasnya berdasarkan gradasi warna dan tingkat kejernihan menjadi 15 peringkat kelas kualitas (Badan Standardisasi Nasional Indonesia, 2001). Kelas kualitas 1 yang dinyatakan sebagai kelas terbaik sampai dengan kelas kualitas 15 yang dinyatakan sebagai kelas terburuk secara berurutan ditandai dengan nama standar mutu: XC, XB, XA, X, WW, WG, N, M, K, I, H, G, F, E, dan D.

Dari dua alinea di atas, dipahami adanya dua realitas, yakni adanya keberagaman mutu gondorukem yang tersedia dan adanya keberagaman penggunaan gondorukem sebagai bahan industri yang secara keseluruhan menghasilkan produk yang sangat beragam. Pada pihak lain, ditemukan pula adanya realitas adanya satu jenis industri tertentu yang menghasilkan suatu satu jenis produk tertentu tetapi disertai dengan tingkat kualitas produk yang beragam, sehingga nilai ekonomi pun juga beragam. Adanya banyak pertimbangan yang dihadapi secara bersama oleh dunia perindustrian yang realitas konkritnya terdiri atas keberagaman jenis industri pengguna gondorukem ini mengakibatkan hadirnya kesepakatan alami tentang preferensi dan segmentasi kualitas gondorukem bagi masing-masing jenis industri. Dengan demikian, masing-masing jenis industri menempatkan diri sesuai dengan karakter spesifiknya pada posisi tertentu didalam memilih dan menggunakan gondorukem sebagai bahan baku.

Dalam konteks ini, industri yang memproduksi minyak rosin memilih untuk menggunakan gondorukem 
kelas mutu D sebagai bahan di dalam proses produksi. Sebagaimana telah dinyatakan, bahwa gondorukem kelas mutu D ini merupakan gondorukem yang memiliki tingkat kualitas yang paling rendah yang ditandai dengan tingkat warna yang paling gelap. Industri yang memproduksi linoleum juga memilih untuk menggunakan gondorukem kelas mutu D sebagai bahan produksi.

Sementara itu, industri yang memproduksi sabun pada umumnya memilih gondorukem yang berkelas mutu $\mathrm{G}$ sampai dengan $\mathrm{K}$ untuk digunakan sebagai bahan pendarih didalam proses produksinya. Apabila sabun yang diproduksi itu direncanakan untuk memiliki kualitas yang lebih tinggi, maka pabrik sabun tersebut akan memilih gondorukem berkualitas M. Lebih lanjut, apabila sabun yang diproduksi itu direncanakan untuk memiliki kualitas yang sangat tinggi, maka pabrik sabun yang bersangkuatn akan memilih gondorukem berkualitas $\mathrm{N}$ dan WG.

Pola pemilihan gondorukem pada industri sabun itu dalam konteks tertentu juga menjadi pola pemilihan bagi industri vernis. Apabila industri ini akan memproduksi vernis berwarna gelap, maka gondorukem berkelas mutu $\mathrm{D}$ akan dipilih sebagai bahan produksi. Selanjutnya, apabila vernis yang berwarna kekuningan dan yang bersifat lebih transparan, maka gondorukem berkelas mutu N, WG, dan WW akan dipilihnya.

\section{METODOLOGI PENELITIAN}

\section{a. Bahan dan Alat Penelitian}

Bahan utama penelitian adalah benda padat tembus cahaya hasil penemuan di wilayah Pecinan di Kecamatan Kutoarjo Kabupaten Purworejo oleh BPCB Jawa Tengah. Bahan-bahan lain yang diperlukan untuk anlisis di laboratorium adalah toluol, alkohol 95\%, larutan standar Kalium hiroksida (KOH) 0,5 N, larutan indikator phenolphtalein (PP) 1\% dalam alkohol 95\%, dan larutan standar $\mathrm{KOH}$ 0,5 N dalam alkohol 95\%.

Alat yang digunakan dalam penelitian meliputi standar warna Lovibond comparator, peralatan penentu warna LICO 620, serangkain alat cincin dan bola baja penentu titik lunak, timbangan analitik, oven listrik, dan cawan porselin. Disamping itu, juga diperlukan alat terbuat dari gelas, yakni termometer gelas, desikator, gelas piala, cawan timbang diameter $55 \mathrm{~mm}$, erlenmeyer $300 \mathrm{ml}$, buret $50 \mathrm{ml}$, dan pipet $25 \mathrm{ml}$.

\section{b. Prosedur Penelitian}

Penelitian untuk mendeskripsikan tentang karakter dan kualitas gondorukem kuna dilakukan dengan mengikuti prosedur pelaksanaan baku yang dipilah menjadi dua tahap secara berurutan, yaitu tahap administrasi perijinan dan tahap pengujian di laboratorium. Tahap administrasi perizinan ditandai dengan penerbitan surat izin pengujian oleh Kepala Perum Perhutani Divisi Regional Jawa Tengah di Semarang. Hal ini disebabkan karena proses pengujian gondorukem kuna ini dilakukan di laboratorium yang dimiliki oleh pabrik gondorukem dan terpentin. Laboratorium ini berada dibawah kewenangan Perum Perhutani Divisi Regional Jawa Tengah. Prosedur untuk mendapatkan surat izin dimulai dengan diterbitkan surat dari Dekan Fakultas Kehutanan Universitas Gadjah Mada yang ditujukan kepada Kepala Perum Perhutani Divisi Regional Jawa Tengah di Semarang yang berisi permohonan izin untuk melaksanakan pengujian kualitas gondorukem di laboratorium yang ada di PGT wilayah kerja Divre Jawa Tengah. Setelah surat perizinan disetujui, maka pengujian di Laboratorium baru dapat dilakukan. Untuk memenuhi prosedur ini, maka diajukan Surat Dekan Fakultas Kehutanan UGM Nomor 270/KS/2016 tertanggal 20 Juni 2016 kepada Kepala Perum Perhutani Divisi Regional Jawa Tengah di Semarang. Kepala Perum Perhutani Divisi Regional Jawa Tengah melalui surat No. 719/016.5/UM/GTD\&MKP/2016 tertanggal 13 Juli 2016 memberikan ijin dan persetujuan bagi pengujian kualitas gondorukem di PGT Sapuran di Wonosobo. Dari Fakultas Kehutanan UGM, surat ijin ini diterima oleh penulis pada tanggal 7 Agustus 2016. Setelah dilakukan koordinasi dengan Kepala PGT Sapuran, maka disepakati bahwa pengujian kualitas gondorukem di Laboratorim PGT Sapuran dapat dilakukan mulai tanggal 10 Agustus 2016.

Jenis-jenis pengujian terhadap gondorukem kuna di laboratorium ini perlu dipilih diantara banyak jenis pengujian yang tersedia. Pemilihan jenis pengujian ini dilakukan berdasarkan pada dua pertimbangan, yaitu (1) volume gondorukem kuna yang tersedia dan (2) jumlah replikasi minimum proses pengujian yang perlu dilakukan agar data hasil pengujian yang dihasilkan memiliki derajat penerimaan pada tingkat kepercayaan cukup tinggi. Pada ranah pertimbangan pertama menunjukkan bahwa volume gondorukem kuna yang tersedia untuk 
diuji ternyata jumlahnya sangat sedikit. Pada ranah pertimbangan kedua didapatkan suatu realitasahwa replikasi proses pengujian yang wajib dilakukan pada taraf minimal adalah sebanyak 3 kali ulangan. Dengan demikian, perlu disediakan tiga contoh uji gondorukem kuna bagi setiap jenis pengujian. Terkait dengan kendalam pegnambilan contoh uji untuk pengujian di laboratorim, maka pengujian terhadap gondorukem ditetapkan hanya terbatas pada empat parameter, yaitu: (1) pengujian warna gondorukem, (2) pengujian titik lunak, (3) pengujian komponen yang menguap, dan (4) pengujian bilangan asam. Prosedur pelaksanaan pengujian bagi masingmasing jenis pengujian itu dideskripsikan sebagai berikut. Pengujian kualitas gondorukem yang dilakukan berdasarkan parameter warna gondorukem ditentukan dengan metode Lovibond Comparator. Lovibond Comparator menyajikan banyak warna yang masingmasing warna itu difungsikan sebagai warna standar. Warna-warna yang tersaji dalam Lovibond Comparator dibedakan satu terhadap yang lain berdasarkan tingkat kejernihan warna standar tersebut. Tingkat kejernihan warna ini sesuai dengan tingkat gelap atau tingkat terang yang dimiliki oleh masing-masing warna standar tersebut. Warna-warna standar ini kemudian disusun dalam suatu urutan secara gradual yang penempatannya ditentukan berdasarkan derajat tingkat kejernihan tersebut. Dengan demikian, ada pemeringkatan warna standar. Setiap warna standar ini mengkonotasikan suatu peringkat tertentu dalam rentang kelas kualitas, sehingga warna tertentu selalu menunjuk pada status kelas kualitas tertentu bagi gondorukem yang diuji.

Dalam konteks pengujian ini, maka warna gondorukem kuna ini dibandingkan dengan standar warna yang ada pada Lovibond Comparator. Contoh uji gondorukem kuna disandingkan dengan warnawarna standar yang ada pada Lovibond Comparator, kemudian warna pada standar yang paling mendekati atau paling mirip dengan warna gondorukem kuna tersebut dipilih dan ditetapkan sebagai warna gondorukem kuna. Berdasarkan warna tersebut, kemudian kualitas gondorukem kuna tersebut dapat ditentukan.

Secara lebih detail, pengujian ini dilaksanakan dengan prosedur berikut.

a. Gondorukem kuna diubah bentuknya dari yang semula berbentuk padat menjadi bentuk serbuk halus. b. Pengubahan bentuk ini dilakukan dengan cara menumbuknya di dalam cawan porselin. Gondorukem berupa serbuk ini dilarutkan dalam cairan toluen dengan perbandingan 1:1 dan dimasukkan dalam gelas tube.

c. Gelas tube yang berisi gondorukem terlarut dalam toluen ini dimasukkan ke dalam alat LICO 620. Nilai tentang peringkat warna yang memperlihatkan oleh alat LICO 620 ini diamati dan dicatat.

d. Nilai hasil peringkat warna ini disandingkan dengan skala tingkat warna pada Lovibond Comparator sehingga diperoleh klasifikasi warna bagi gondorukem kuna tersebut. Klasifikasi warna ini kemudian menjadi dasar untuk menentukan peringkat kualitas gondorukem kuna tersebut.

Pengujian kualitas gondorukem berdasarkan parameter titik lunak dilakukan untuk menentukan tingkat suhu yang menandai saat awal gondorukem itu mulai melunak. Pengujian dilakukan berdasarkan SNI 7636: 2011 dengan prosedur sebagai berikut.

a. Gondorukem dihaluskan untuk mencapai dimensi tertentu sedemikian rupa sehingga gondorukem itu berubah dari bentuk bongkah padat menjadi serbuk halus.

b. Serbuk ini dicairkan dengan suhu rendah dan dimasukkan dalam ring dan permukaan gondorukem ini diratakan di dalam ring.

c. Ring ini dimasukkan dalam ring holder. Bola baja diletakkan pada permukaan gondorukem. Ring tersebut bersama dengan termometer dimasukkan ke dalam gelas piala yang berspesifikasi tertentu, yakni volume $800 \mathrm{ml}$, tinggi $14-15 \mathrm{~cm}$, diameter 9,5-10,5 cm.

d. Air suling diisikan ke dalam gelas piala sedemikian rupa sehingga permukaan air suling ini memiliki ketinggian 10,16 - 10,78 cm.

e. Memanaskan air secara sangat perlahan yang dimulai dari suhu $40 \circ \mathrm{C}$ sembari mengamati dan mencatat terhadap:

(1) tingginya suhu awal yang menyatakan saat gondorukem mulai melunak dan ditandai oleh bola baja mulai bergerak menurun dari permukaan gondorukem

(2) suhu akhir yang ditandai dengan saat bola baja itu menyentuh bagian dasar lempeng.

(3) Menentukan titik lunak dengan cara menghitung nilai rata-rata suhu awal ketika bola baja mulai bergerak menurun dan suhu akhir ketika bola baja ini menyentuh 
dasar lempeng. Nilai suhu rata-rata ini kemudian ditetapkan sebagai titik lunak gondorukem.

Pengujian kualitas gondorukem berdasarkan parameter komponen yang menguap merupakan pengujian yang dimaksudkan untuk mengetahui banyaknya bagian yang mudah menguap dari gondorukem. Pengujian ini dilaksanakan dengan prosedur berikut.

a. Mengubah gondorukem yang semula berbentuk padat menjadi bentuk serbuk halus dengan cara penumbukan di dalam cawan porselin.

b. Gondorukem berupa serbuk ini disediakan dalam jumlah tertentu yang beratnya 2,5 gram. Gondorukem serbuk tersebut dimasukkan ke dalam cawan timbang berdiameter $55 \mathrm{~mm}$ yang beratnya sudah diketahui dengan cara penimbangan cawan itu sebelum dimasuki gondorukem tersebut.

c. Cawan berisi gondorukem ini dimasukkan ke dalam oven listrik yang telah diatur pada kondisi suhu $150+5$ oC dan dibiarkan selama 1 jam di dalam oven tersebut dalam rangka diberikan perlakuan pemanasan.

d. Cawan berisi gondorukem panas itu dikeluarkan dari oven dan dimasukkan ke dalam desikator selama lima menit, kemudian ditimbang. Berat cawan berisi gondorukem ini dicatat.

e. Perlakuan berurutan berupa pemanasan cawan berisi gondorukem di dalam oven selama 1 jam yang diikuti dengan pendinginan di dalam desikator selama 5 menit serta ditindaklanjuti dengan penimbangan tersebut dilakukan secara berulang-ulang, sedemikan rupa sehingga diperoleh berat yang konstan. Berat komponen yang menguap dihitung dengan menggunakan rumus: $\mathrm{Km}=\{(\mathrm{W} 1-\mathrm{W} 2) /(\mathrm{W} 1-\mathrm{W})\} \times 100 \%$. Notasi terhadap simbol yang digunakan dalam rumus ini adalah sebagai berikut. $\mathrm{Km}$ adalah komponen yang mudah menguap. W adalah berat cawan dalam kondisi kosong. W1 adalah berat cawan berisi serbuk gondorukem. W2 adalah berat konstan cawan berisi serbuk gondorukem setelah dipanaskan berulang-ulang.

Pengujian kualitas gondorukem berdasarkan parameter bilangan asam merupakan pengujian yang dimaksudkan untuk mengetahui tingkat keasaman gondorukem. Pengujian ini dilaksanakan dengan prosedur berikut.

a. Mengubah gondorukem yang semula berbentuk padat menjadi bentuk serbuk halus dengan cara menumbuknya.

b. Gondorukem berbentuk serbuk ini disediakan dalam jumlah tertentu yang beratnya 4 gram. Gondorukem serbuk tersebut dimasukkan ke dalam erlenmeyer pertama berkapasitas $300 \mathrm{ml}$ yang beratnya sudah diketahui dengan cara penimbangan erlenmeyer itu sebelum dimasuki gondorukem tersebut.

c. Disediakan erlenmeyer kedua dengan spesifikasi yang sama dengan erlenmeyer pertama. Ke dalam erlenmeyer kedua ini dimasukkan alkohol sebanyak $100 \mathrm{ml}$ dan dipanaskan sehingga mencapai kondisi mendidih.

d. Pada suhu diatas $70 \circ \mathrm{C}$, alkohol ini dinetralkan dengan menggunakan cairan kalium hidroksida $(\mathrm{KOH}) \quad 0,5 \mathrm{~N}$ dan ditambahkan dengan PP sebanyak 0,5 ml.

e. Alkohol dalam kondisi panas ini dituangkan dari erlenmeyer kedua menuju ke dalam erlenmeyer pertama yang berisi contoh uji gondorukem. Dalam kondisi panas, alkohol di dalam erlenmeyer pertama itu dititrasi secara terus menerus dengan menggunakan $\mathrm{KOH} \mathrm{0,5}$ $\mathrm{N}$.

f. Proses titrasi dihentikan ketika penambahan satu tetes cairan $\mathrm{KOH}$ 0,5 $\mathrm{N}$ yang bersifat basa ini mengakibatkan perubahan warna yang jelas dan dapat bertahan selama 15 detik.

g. Bilangan asam yang dimiliki oleh gondorukem ini dihitung dengan menggunakan rumus: $\mathrm{Ba}=(\mathrm{V} \times \mathrm{N}$ x 56,1) / W. Notasi terhadap simbol yang digunakan dalam rumus ini adalah sebagai berikut. $\mathrm{Ba}$ adalah bilangan asam gondorukem. $\mathrm{V}$ adalah volume total $\mathrm{KOH}$ 0,5 $\mathrm{N}$ yang diperlukan untuk melakukan proses titrasi dan dinyatakan dalam satuan mililiter. $\mathrm{N}$ adalah nilai normalitas $\mathrm{KOH}$ yang besarnya telah ditentukan, yakni 0,5 . W adalah berat contoh uji gondorukem, yaitu 4 gram. Angka 56,1 adalah nilai yang menggambarkan berat molekul $\mathrm{KOH}$.

\section{c. Kodifikasi Gondorukem Kuna dalam Proses Pengujian}

Penelitian dilakukan melalui pengujian dengan replikasi tiga kali. Ulangan pertama, kedua dan ketiga diberi kode $\mathrm{A}, \mathrm{B}$, dan $\mathrm{C}$ secara berurutan.

\section{HASIL PENELITIAN DAN PEMBAHASAN}

Hasil penelitian gondorukem kuna dipilah menjadi empat bagian, yaitu (1) warna gondorukem, (2) 
titik lunak, (3) komponen yang menguap, dan (4) bilangan asam. Masing-masing hasil pengujian disajikan sebagai berikut.

\section{a. Warna Gondorukem}

Hasil penelitian terhadap tingkat warna gondorukem kuna dan status kelas kualitasnya disajikan pada Tabel 3 berikut.

Tabel 3. Hasil pengujian warna gondorukem kuna.

\begin{tabular}{|c|c|c|c|}
\hline Replikesi pengujam & Kode gondorukem & 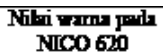 & 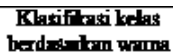 \\
\hline 1 & $\mathbf{A}$ & 10,4 & $\mathbf{M}$ \\
\hline 7 & B & 115 & I \\
\hline 3 & C & 114 & I \\
\hline \multicolumn{2}{|c|}{ Nini raternata } & 11,1 & $\overline{\mathbf{I}}$ \\
\hline
\end{tabular}

Berdasarkan Tabel 3, terlihat bahwa gondorukem kuna memiliki nilai warna rata-rata sebesar 11,1 dengan kisaran nilai terendah 10,4 pada ulangan pertama dan nilai tertinggi 11,5 pada ulangan kedua. Berdasarkan pembandingan nilai ini terhadap standar warna Lovibond, maka nilai warna sebesar 11,1 ini termasuk dalam kategori kelas mutu gondorukem I. Dengan demikian, gondorukem kuna ini berada pada peringkat kelas kualitas ke-10 dari 15 kelas kualitas yang tersedia berdasarkan SNI. Dengan kelas mutu I itu, dapat dikatakan bahwa status kelas kualitas gondorukem ini termasuk dalam kategori kualitas yang rendah atau buruk.

Status kelas kualitas gondorukem kuna yang rendah ini diperkuat dengan penampilannya yang didominasi oleh warna coklat-kehitaman. Apabila warna dan tingkat kejernihan gondorukem kuna ini dikomparasikan dengan warna dan kejernihan gondorukem yang berkelas kualitas X dan WW, maka penampilan ketiganya dapat dilihat pada Gambar 1 berikut.

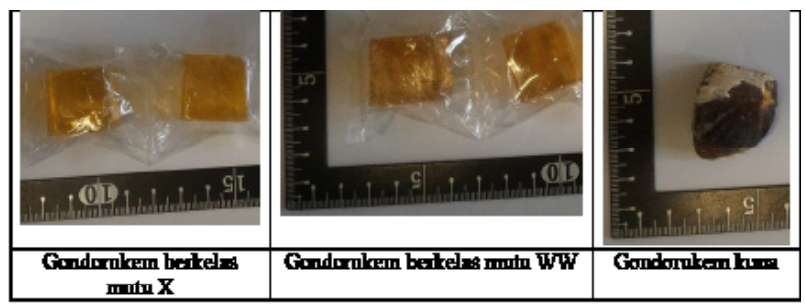

Gambar 1. Pembandingan gondorukem berkelas mutu X, WW, dan gondorukem kuna

\section{b. Titik Lunak}

Hasil penelitian titik lunak gondorukem kuna disajikan pada Tabel 4 berikut.

Tabel 4. Hasil pengujian titik lunak gondorukem kuna.

\begin{tabular}{|c|c|c|c|c|}
\hline \multirow{2}{*}{$\begin{array}{l}\text { Replikaxi } \\
\text { Pengüimm }\end{array}$} & \multirow{2}{*}{$\begin{array}{l}\text { Kode } \\
\text { gondonikem }\end{array}$} & \multicolumn{2}{|c|}{$\begin{array}{c}\text { Solhn termometer bola kering (CC) } \\
\text { padp paxisi }\end{array}$} & \multirow{2}{*}{$\begin{array}{c}\text { Till humak } \\
\text { gimilnukem } \\
\text { (C) }\end{array}$} \\
\hline & & Fii & frimn & \\
\hline 1 & $\mathbf{A}$ & 81 & 82 & 81,5 \\
\hline 2 & B & 75 & 76 & 35,5 \\
\hline$\overline{3}$ & $\overline{\mathbf{C}}$ & 73 & 75 & 34,0 \\
\hline \multicolumn{4}{|c|}{ N]17i rata-rata } & 7 \\
\hline
\end{tabular}

Berdasarkan Tabel 4, terlihat bahwa gondorukem kunamemiliki nilai titik lunak rata-rata 77 oC dengan kisaran nilai terendah 74 oC pada ulangan ketiga dan nilai tertinggi 81,5 oC pada ulangan pertama. Dalam upaya pembandingan nilai ini terhadap nilai standar titik lunak pada kelas $\mathrm{N}$ sampai dengan X yang berkisaran 74 sampai dengan 78 oC sebagaimana tersaji pada Tabel 2, maka nilai titik lunak gondorukem kuna sebesar 77 oC ini berada pada posisi yang mendekati titik lunak kelas kualitas X. Dengan kata lain, nilai titik lunak gondorukem kuna termasuk dalam kisaran wilayah titik lunak gondorukem yang diproduksi di Indonesia pada saat ini. Dengan demikian, maka gondorukem kuna ini merupakan gondorukem yang wajar dan normal. Dengan parameter nilai titik lunak ini, maka dapat dipastikan bahwa tidak ditemukan adanya anomali dan keraguan untuk menetapkan benda kuna yang ditemukan di Kutoarjo ini sebagai gondorukem.

\section{c. Pengujian Komponen yang Menguap}

Hasil pengujian terhadap komponen yang menguap pada gondorukem kuna disajikan pada Tabel 5 berikut.

Tabel 5. Hasil pengujian komponen yang menguap pada gondorukem kuna.

\begin{tabular}{|c|c|c|c|c|c|}
\hline \multirow[b]{2}{*}{ 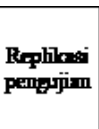 } & \multirow[b]{2}{*}{$\begin{array}{c}\text { Kode } \\
\text { gandmakem }\end{array}$} & \multicolumn{3}{|c|}{ 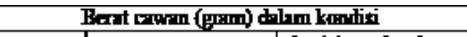 } & \multirow[b]{2}{*}{$\begin{array}{c}\text { Kadar } \\
\text { kmimponen } \\
\text { mergarp } \\
\text { (\%) }\end{array}$} \\
\hline & & knsong & 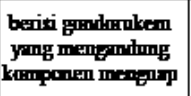 & 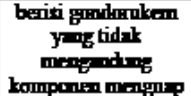 & \\
\hline T & $\overline{\mathbf{A}}$ & 14,503 & 17,005 & 16,857 & 5,915 \\
\hline 2 & B & 14,055 & 16,565 & 16,415 & 6,000 \\
\hline 3 & $\overline{\mathbf{C}}$ & 14315 & 16815 & 16,691 & 4,950 \\
\hline \multicolumn{5}{|c|}{ Nitirthth } & 5,628 \\
\hline
\end{tabular}

Berdasarkan Tabel 5, terlihat bahwa gondorukem kuna memiliki kadar komponen yang menguap dengan nilai rata-rata sebesar 5,628\% dengan kisaran nilai terendah 4,960\% pada ulangan ketiga dan nilai tertinggi 6,00\% pada ulangan kedua. Dalam upaya pembandingan nilai ini terhadap kadar komponen yang menguap pada kelas kualitas X sampai dengan $\mathrm{N}$ sebagaimana tersaji pada Tabel 2, yang nilainya berada pada kisaran 2 sampai dengan 3, maka terlihat bahwa nilai kadar komponen mudah menguap yang dikandung dalam gondorukem kuna ini tergolong sangat tinggi. Kadar komponen mudah 
menguap yang sangat tinggi di dalam gondorukem kuna ini dapat dimaklumi berdasarkan landasan rasionalitas sebagai berikut.

Komponen mudah menguap yang dikandung dalam gondorukem adalah terpentin. Sebagaimana dipahami, bahwa gondorukem dan terpentin merupakan dua komponen yang bersenyawa dan menyatu di dalam suatu benda cair yang berwujud getah pinus. Dalam proses distilasi terhadap getah pinus tersebut, terjadi proses pemisahan antara dua komponen ini. Dalam pemisahan itu, gondorukem tertinggal di dalam tangki distilasi, sedangkan terpentin menguap dan meninggalkan tangki distilasi. Derajat pemisahan terpentin terhadap gondorukem bergantung pada status teknologi distilasi yang diterapkan. Semakin tinggi status dan tingkatan teknologi distilasi yang diterapkan, semakin tinggi daya pemisahan terpentin terhadap gondorukem. Selanjutnya, semakin tinggi daya pemisahan terpentin terhadap gondorukem akan berakibat pada semakin besar pula komponen terpentin yang terpisahkan dari gondorukem, dengan demikian semakin sedikit terpentin yang terkandung di dalam gondorukem.

Teknologi distilasi getah pinus berkembang melalui beberapa tahapan dan setiap tahapan itu menghasilkan status teknologi distilasi tertentu. Perkembangan teknologi ini berawal dari status yang berkualifikasi sederhana menuju ke status yang berkualifikasi semakin canggih dan semakin modern. Dalam konteks distilasi getah pinus, teknologi tersebut berkembang dari status penggunaan pemanasan secara langsung, menuju ke tahapan penggunaan pemanasan secara tidak langsung dengan memanfaatkan uap air sebagai media pembawa panas. Teknologi distilasi tidak langsung ini kemudian berkembang lagi dari status penerapan tekanan atmosferik di dalam tangki distilasi menuju ke tahapan penerapan tekanan hampa, bahkan dengan derajat kehampaan yang semakin tinggi. Penerapan status teknologi distilasi yang semakin modern akan mendorong terbentuknya gondorukem yang semakin bebas dari kandungan terpentin, sehingga gondorukem yang dihasilkannya mengandung terpentin yang semakin sedikit.. Seiring dengan itu, maka gondorukem yang dihasilkan akan bergeser dari kelas kualitas rendah yaitu I atau M menuju ke kelas kualitas tinggi yaitu WW atau
X. Berdasarkan uraian tersebut dapat disimpulkan bahwa kualitas $\mathrm{M}$ dan I gondorukem kuno dihasilkan dari teknologi yang menerapkan pemanasan langsung yang dilaksanakan pada tekanan atmosferik pada bejana distilasi.

\section{d. Pengujian Bilangan Asam}

Hasil pengujian bilangan asam gondorukem kuna disajikan pada Tabel 6 berikut.

Tabel 6. Hasil pengujian bilangan asam gondorukem kuna.

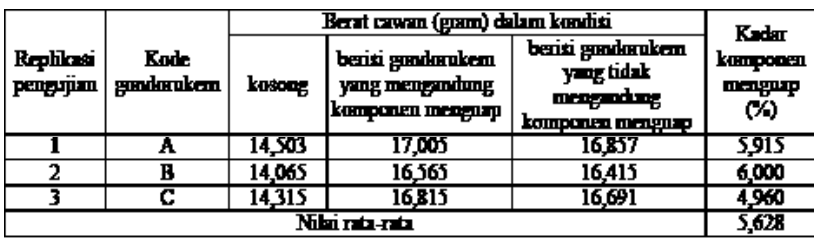

Catatan: volume contoh uji berkode $\mathrm{C}$ tidak cukup untuk dilaksanakan pengujian.

Berdasarkan Tabel 6, terlihat bahwa gondorukem kuna memiliki bilangan asam dengan nilai rata-rata sebesar 145,941 dengan kisaran nilai 145,777 pada contoh uji A dan nilai 146,105 pada contoh uji B. Dalam pengujian bilangan asam, data gondorukem berkode C tidak tersedia. Ketidakadaan data ini disebabkan gondorukem berkode $\mathrm{C}$ tidak dilakukan pengujian. $\mathrm{Hal}$ ini disebabkan karena jumlah gondorukem berkode $\mathrm{C}$ yang tersedia sangat sedikit, sehingga telah terbagi habis untuk pengujian: warna, titik lunak, dan komponen yang menguap. Dengan demikian, gondorukem berkode C tidak tersedia untuk pengujian bilangan asam.

Nilai bilangan asam pada gondorukem pada umumnya berisar antara 160-190. Penelitian secara khusus dilakukan Khadafi dkk., (2014) terhadap gondorukem yang dihasilkan dari PGT Sindang Wangi di Provinsi Jawa Barat mendapatkan bilangan asam sebesar 179,92 bagi gondorukem berkualitas X dan 176,58 sebesar bagi gondorukem berkualitas WW.

Dalam upaya pembandingan nilai bilangan asam gondorukem kuna ini terhadap nilai bilangan asam gondorukem secara umum, maupun secara khusus terhadap kelas kualitas X dan kelas kualitas WW sebagaimana tersaji pada alinea di atas, maka terlihat bahwa nilai bilangan asam pada gondorukem kuna ini tergolong sangat rendah. Status nilai rendah ini terlihat dari nilai bilangan asam gondorukem kuna sebesar 145,941, sedangkan nilai bilangan asam gondorukem 
pada umumnya adalah 160-190 dan nilai pada kelas kualitas X adalah 179,92.

Nilai bilangan asam yang sangat rendah di dalam gondorukem kuna ini karena bilangan asam. Bilangan asam merupakan bilangan yang menggambarkan banyaknya kalium hidroksida $(\mathrm{KOH})$ dalam satuan miligram yang diperlukan untuk menetralkan satu gram asam resin yang terkandung dalam senyawa gondorukem (RSNI3 7636: 2010). Selain itu, bilangan asam juga digunakan untuk mengetahui jumlah asam lemak bebas yang terkandung dalam gondorukem. Pada gilirannya, bilangan asam ini digunakan untuk mengetahui tingkat kerusakan bahan yang disebabkan adanya proses hidrolisis atau distilasi. Dengan demikian, nilai bilangan asam yang rendah menggambarkan rendahnya tingkat kerusakan terjadi pada asam lemak bebas dalam gondorukem kuna. Rendahnya jumlah asam lemak bebas yang mengalami kerusakan itu dimungkinkan sebagai akibat dari proses distilasi pada suhu rendah yang diterapkan pada saat pembuatan gondorukem kuna tersebut.

Dengan demikian, realitas gondorukem kuna yang nilai bilangan asam yang rendah ini seiring dengan nilai kadar komponen menguap yang tinggi. Hal ini disebabkan oleh proses distilasi pada tahap teknologi awal, yakni proses distilasi yang dilakukan dengan menerapkah suhu rendah.

\section{e. Interpretasi terhadap Penemuan Gondorukem} Kuna.

Penemuan gondorukem kuno ini memicu pertanyaan tentang jenis industri apa pada masa yang lalu berkait dengan gondorukem kuno. Pertanyaan ini dijawab dengan metode analisis rasional dan interpretasi yang dilakukan dengan mempertimbangkan dan memanfaatkan data dan informasi yang ada. Data dan informasi ini dipilah menjadi tiga perspektif, yaitu meliputi: (1) ontologi ilmu pengetahuan dan teknologi yang mendiskripsikan tentang mata rantai dan segmentasi pengolahan yang berkait dengan gondorukem, (2) data hasil penelitian ini, dan (3) informasi tentang kondisi dan situasi yang menggambarkan tentang realitas pada saat benda kuna tersebut ditemukan.

Dalam konteks perspektif pertama, ada pemahaman adanya mata rantai pengolahan gondorukem. Mata rantai ini dapat dibedakan menjadi tiga segmen, yaitu segmen pengolahan: awal, tengah, dan akhir. Segmen pengolahan awal adalah pengolahan yang mengubah getah pinus menjadi gondorukem. Segmen pengolahan tengah adalah pengolahan yang mengubah gondorukem menjadi derivat gondorukem. Segmen pengolahan akhir adalah pengolahan yang menempatkan gondorukem atau derivat gondorukem sebagai salah satu bahan baku yang bersama dengan bahan baku lainnya untuk diproses demi memproduksi suatu produk akhir.

Dalam konteks perspektif kedua, ditemukan realitas bahwa gondorukem kuna ini berkelas mutu $\mathrm{M}$ dan I. Gondoruken ini memiliki kadar komponen menguap yang tinggi, dan nilai titik lunak yang wajar, serta bilangan asam yang bernilai rendah.

Dalam konteks perpektif ketiga, ada dua sumber informasi. Sumber informasi pertama diperoleh dari Kepala BPCB Jawa Tengah sebagaimana tertuang dalam surat No. 1194/E19/KB/2017 tertanggal 3 April 2017. Informasi ini terdiri atas dua hal, yaitu: (1) gondorukem kuna ditemukan dalam wajan raksasa, berada dalam jumlah yang tidak banyak dan sebagian telah diambil oleh penduduk yang menemukannya, (2) gondorukem berada di dalam wajan dan tidak ditemukan barang yang lain selain gondorukem ini. Sumber informasi kedua diperoleh dari Parwito (2016) yang mempublikasikan beberapa informasi melalui surat kabar Media.com. Informasi ini terdiri atas tiga hal yang semuanya berkait dengan keberadaan wajan kuna, yaitu (1) wajan berbahan baja dengan diameter $270 \mathrm{~cm}$ dan dimensi tinggi atau kedalaman cekungan $90 \mathrm{~cm}$, (2) wajan tertanam pada pasangan batu bata kuna berukuran besar yang diduga sebagai bekas tungku minyak tanah, dan (3) wajan merupakan peninggalan pabrik yang beroperasi ratusan tahun lalu.

Apabila aspek ontologi ilmu pengetahuan sebagai perspektif pertama disintesiskan dengan aspek data hasil penelitian sebagai perspektif kedua, maka keberadaan gondorukem kuna itu memiliki kemungkinan untuk mengarah pada industri yang berada pada segmen pengolahan akhir. Bersama dengan batasan bahwa gondorukem kuna ini berkelas kualitas $\mathrm{M}$ atau I, maka aktivitas produksi segmen pengolahan akhir tersebut akan mengarah pada tiga kemungkinan, yaitu: (1) aktivitas produksi yang menghasilkan produk akhir berupa linoleum dalam industri minyak, (2) aktivitas produksi 
yang menghasilkan produk akhir yang dalam Bahasa Jawa disebut "malam", yaitu produk sejenis lilin yang digunakan untuk membuat motif dalam industri batik, atau (3) aktivitas produksi yang menghasilkan produk akhir berupa berupa sabun dalam industri sabun.

Sementara itu, apabila aspek ontologi ilmu pengetahuan sebagai perspektif pertama disintesiskan dengan aspek informasi tentang kondisi dan situasi saat penemuan sebagai perspektif ketiga, maka keberadaan gondorukem kuna itu memiliki kemungkinan yang mengarah pada aktivitas industri yang berada pada segmen pengolahan awal. Industri yang berstatus pada segmen awal ini mengarah pada satu kemungkinan saja, yaitu aktivitas produksi yang mengolah bahan baku berupa getah pinus untuk menghasilkan produk akhir berupa gondorukem. Dengan demikian, kemungkinan yang terakhir ini dapat diurutkan sebagai kemungkinan yang keempat, setelah adanya kemungkinan pertama sampai dengan ketiga sebagaimana disebut dalam alinea di atas.

Apabila keempat kemungkinan jenis industri itu dikomparasikan, maka kemungkinan industri yang keempat akan memiliki peluang kebenaran yang paling kuat, sehingga dugaan akan mengerucut pada jenis industri yang mengolah getah pinus menjadi gondorukem. Kebenaran terhadap kemungkinan keempat ini didukung oleh tiga hal, yaitu (1) gondorukem ini berada di dalam wajan raksasa dan tidak ditemukan barang lain di dalam wajan itu selain gondorukem tersebut, (2) gondorukem kuna ini merupakan gondorukem yang murni. Kemurnian ini ditandai dengan tidak adanya kerusakan yang cukup signifikan dialami oleh gondorukem tersebut, meskipun telah terpendam selama ratusan tahun di dalam situs tersebut. (3) Gondorukem ini memiliki mutu yang rendah, yakni berkelas kualitas I. Mutu yang rendah ini merupakan konsekuensi logis dari proses distilasi yang diterapkan pada saat silam itu, yakni distilasi dengan teknologi tahap awal dan sederhana. Teknologi distilasi demikian ditandai oleh proses pemasakan yang dilakukan pada tekanan atmosferik di dalam wajan raksasa yang terbuka dan ditempatkan di atas bangunan tungku perapian dengan pemanasan secara langsung dengan sumber api yang berasal dari kompor minyak. Sementara itu, tingkat kemungkinan yang mengarah kepada industri minyak linoleum, industri batik maupun industri sabun menjadi sangat rendah. Hal ini disebabkan karena ketiga industri tersebut selalu memerlukan bahan lain sebagai pencampur terhadap gondorukem dalam proses produksinya. Adanya realitas bahwa gondorukem kuna berada di dalam wajan raksasa dan tidak ditemukan barang lain di dalam wajan itu selain gondorukem tersebut merupakan realitas yang menafikan adanya kemungkinan bagi ketiga industri tersebut.

Berdasarkan uraian tentang pembandingan antara keempat kemungkinan industri tersebut di atas, maka menjadi jelaslah bahwa kemungkinan keempat merupakan kemungkinan yang secara rasional paling kuat. Hal ini disebabkan karena kemungkinan keempat mendapatkan dukungan data dan infomasi yang paling banyak, baik dukungan dari perpektif: ontologi ilmu pengetahuan, data yang diperoleh dari hasil penelitian maupun informasi yang diperoleh dari BPCB Jawa Tengah maupun dari media masa. Dengan demikian, keberadaan gondorukem kuna ini berkonotasikan pada adanya industri pengolahan getah pinus untuk memproduksi gondorukem yang beroperasi pada masa silam.

\section{KESIMPULAN DAN SARAN}

Ada empat butir kesimpulan, yaitu:

1. Berdasarkan karakter sifat fisik yang meliputi warna, derajat ketransparanan, tingkat kerapuhan, struktur dan posisi bidang patahan pada permukaan benda, maka benda kuna temuan di Kecamatan Kutoarjo adalah gondorukem.

2. Gondorukem kuna memiliki kelas kualitas yang rendah, yaitu kelas mutu I yang menempati peringkat ke-10 dari 15 peringkat kelas kualitas.

3. Gondorukem kuna memiliki nilai titik lunak yang wajar, kadar komponen menguap yang tinggi dan nilai bilangan asam yang rendah.

4. Keberadaan gondorukem kuna yang soliter di dalam wajan berukuran raksasa mengindikasikan adanya kegiatan industri pengolahan terhadap getah pinus menjadi produk gondorukem pada lokasi tempat ditemukannya.

Sebuah saran disampaikan, yaitu bahwa pengumpulan informasi dan data tentang berbagai aspek yang berkait gondorukem kuna ini perlu dilakukan secara terusmenerus sehingga interpretasi mengenai kegiatan dan peradaban masa lalu sebagaimana tertuang dalam butir kesimpulan yang keempat tersebut dapat dipertajam. 


\section{DAFTAR PUSTAKA}

Abdulgani, M., 2002. Gondorukem dan Terpentin di Indonesia. Perum Perhutani Unit I Jawa Tengah. Semarang.

Astuti, S.S., 2015. Perpanjangan Daur Tebang Hutan Pinus. Komunikasi pribadi.

Badan Standardisasi Nasional, 2001. Gondorukem Indonesia. Standar Nasional Indonesia SNI 01.5009.12-2001, RSNI3 7636: 2010, dan SNI 7636: 2011. Jakarta.

Endom, W. 1989. Penyadapan Getah Pinus dengan Sistem Portugis. Majalah Duta Rimba No. 107108/XV/1989. Perum Perhutani. Jakarta.

Kasmudjo. 2011. Hasil Hutan non kayu. Cakrawala media. Yogyakarta.

Khadafi Mahammad, Ike Rostika, Taufan Hidayat, 2014. Pengolahan Gondorukem Menjadi Bahan Pendarihan sebagai Aditif pada Pembuatan Kertas. Jurnal Selulosa, Vol. 4, No. 1, Juni 2014 :17-24. Balai Besar Selulosa, Bandung.

Kirk, R. E dan Othmer, D. F. 2007. Encyclopedia of Chemical Technology 4th. Volume Ke-21. The Interscience Encyclopedia, Inc. New York.

Martawijaya, A., Kartasujana, I., Mandang, Y.I., Prawira, Kadir, K., 1989. Atlas Kayu Indonesia. Jilid I. Lembaga Penelitian dan Pengem bangan Kehutanan, Departemen Kehutanan. Bogor.

Parwito, 2016. Misteri Penemuan Wajan Raksasa di Tengah Kota Kutoarjo. Sumber: https://www. merdeka.com/peristiwa/misteri-penemuanwajan-raksasa-di-tengah-kota-sukoarjo.html. Diunduh tanggal 4 April 2017.

Perum Perhutani, 1985. Pedoman Penyadapan Getah Pinus dengan Sistem Kowakan. SK Direksi Perhutani No. 688/KPTS/DIR/1985, Tanggal 8 Oktober 1985.

1992. Pedoman Penyadapan Getah Pinus dengan Sistem Saluran (Metoda Rill). SK Direksi Perhutani No. 879/KPTS/DIR/1992, Tanggal 27 Agustus 1992.

2010. Potensi Sumberdaya Hutan di Pulau Jawa. Ditjenbun. Jakarta.

Siregar, EBMS. 2005. Pemuliaan Pinus Merkusii. Fakultas Pertanian. Jurusan Kehutanan. Universitas Sumatera Utara. Medan.
Soenardi, A. 1980. Pembinaan dan Pengembangan Potensi Produksi Hasil Hutan Non Kayu. Prosiding Diskusi Hasil Hutan Non kayu. Jakarta, 10-12 Juli 1980.

Soeseno, O.H., Hardiyanto, E.B., Suhardi, dan Na'iem, 1992. Status Pemuliaan Pohon dan Bioteknologi Hutan di Indonesia Saat Ini. Prosiding Seminar Nasional Status Silvikultur di Indonesia Saat Ini. Kerjasama antara Departemen Kehutanan, Asosiasi Pengusaha Hutan Indonesia, dan Fakultas Kehutanan Universitas Gadjah Mada Yogyakarta. Yogyakarta.

Sumantri, I. 1991. Perbaikan Sistem Penyadapan Getah Pinus untuk Meningkatkan Hasil Getah. Jurnal Penelitian dan Pengembangan Kehutanan 7 (2): 21-25. Badan Litbang Kehutanan. Jakarta.

Sumantri, I., dan W. Endom. 1989. Penyadapan Getah Pinus Merkusii dengan Menggunakan Beberapa Pola Sadap dan Tingkat Konsentrasi Zat Perangsang. Jurnal Penelitian Hasil Hutan 6 (3): 152-159. Puslitbang Hasil Hutan. Bogor.

Suryamiharja, S., dan Buharman. 1986. Hasil Hutan Non Kayu di Indonesia. Sylvatropika 1 (1): 3-5. Badan Litbang Kehutanan. Jakarta. 